\title{
A physical activity assessment of Wroclaw Medical University students with IPAQ - long questionnaire: a cross sectional study
}

\author{
Ocena aktywności fizycznej studentów Uniwersytetu Medycznego we Wrocławiu \\ na podstawie kwestionariusza IPAQ - long: badanie przekrojowe
}

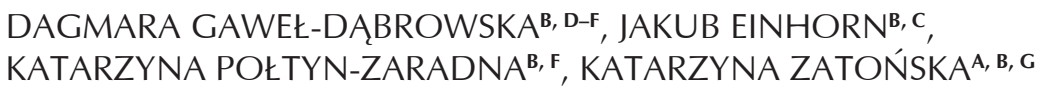

Department of Social Medicine, Wroclaw Medical University

A - Study Design, B - Data Collection, C - Statistical Analysis, D - Data Interpretation, E - Manuscript Preparation,

$\mathbf{F}$ - Literature Search, G - Funds Collection

Summary Background. Polish society is characterized with low physical activity. Medical University students, as future doctors, should not only understand the importance of physical activity, but also do all they can to actively propagate it.

Objectives. The aim of conducted research was to assess the level of physical activity among students of the final study year of Medical and Dentistry Faculties of Wroclaw Medical University.

Material and methods. Study group included 211 people. In term of age and gender students of both faculties were a homogenous group. The study was conducted in summer term of 2011/2012 academic year, auditory method, ensuring anonymity. The study tool was International Questioner of Physical Activity (IPAQ) - long form. Based on METs values the authors distinguished three levels of total physical activity - intense, moderate and low.

Results. The level of students' physical activity is comparable between the faculties with slightly higher values for students of Dentistry Faculty. Distributions of three levels of physical activity were similar between the faculties.

Conclusions. The present study showed a need of health promotion in contests of physical activity among students of both faculties. The lowest activity of them (both male and female) is in the domain of work-related, during academic year. It creates a need for modifications of the study curriculum by adding additional sport classes and promoting attitudes of undertaking physical activity during other than study related activities.

Key words: physical activity, IPAQ, students, Medical University.

Streszczenie Wstęp. Polskie społeczeństwo charakteryzuje niska aktywność fizyczna. Studenci Uniwersytetu Medycznego jako przyszli lekarze powinni nie tylko rozumieć znaczenie aktywności fizycznej, ale również aktywnie ją propagować. Cel pracy. Celem przeprowadzonego badania była ocena poziomu aktywności fizycznej studentów ostatnich lat studiów na wydziałach: Lekarskim oraz Lekarsko-Stomatologicznym Uniwersytetu Medycznego we Wrocławiu.

Materiał i metody. Grupę badawczą stanowiło 211 osób. Na obu wydziałach nie zaobserwowano różnic pod względem płci i wieku. Badanie było przeprowadzone w semestrze letnim roku akademickiego 2011/2012 metodą ankietową z zachowaniem anonimowości. Narzędzie badawcze stanowił Międzynarodowy Kwestionariusz Aktywności Fizycznej (IPAQ) - forma długa, w którym pytaliśmy o aktywność w czasie: pracy, pobytu w domu, w czasie wolnym, w trakcie przemieszczania się Na podstawie wartości METs określiliśmy trzy poziomy całkowitej aktywności fizycznej - intensywną, umiarkowaną i niską. Wyniki. Poziom aktywności fizycznej studentów na obu wydziałach jest zbliżony z nieznacznie wyższymi wartościami dla studentów Wydziału Lekarsko-Stomatologicznego. Rozkład trzech poziomów aktywności jest podobny dla obu wydziałów. Wnioski. Badanie wykazało potrzebę promowania aktywności fizycznej wśród studentów obu wydziałów. Najniższą aktywnością wykazały się zarówno kobiety, jak i mężczyźni w obszarze związanym z pracą zawodową, w czasie roku akademickiego. Należy zwrócić uwagę na potrzebę zmodyfikowania programu studiów przez zwiększenie liczby godzin ćwiczeń fizycznych oraz promowanie podejmowania aktywności fizycznej w czasie wolnym od zajęć związanych ze studiowaniem. Słowa kluczowe: aktywność fizyczna, IPAQ, studenci, Uniwersytet Medyczny.

\section{Background}

Physical activity is an intentionally directed activity of man, it is any work done by skeletal muscles characterized with energy expenditure above resting [1]. We are exposed to such activity on everyday basis - when working at home, at work and during the leisure time. Physical activity of leisure time can be spontaneous (i.e. marching, walking, running) or can be planned in respect to exposure to level of activity [2]. Planning and performing of adequate physical activity is one of the basic pro-health activities against risks of cardiovascular, respiratory, neural, musculoskeletal disorders. It also prevents obesity, diabetes, cancer diseases. People maintaining high physical activity for a long time show $25-30 \%$ reduction of mortality due to cancer diseases, some studies show that men maintaining high physical activity have as much as $59 \%$ reduction of cancer mortality [3]. Meta-analysis of nearly 170 cohort studies indicates 
that regular physical exercises reduce incidence of malignant cancers of colon, nipple and most likely prostate, lungs and endometrium [4]. Inactive lifestyle leads to lower level of physical abilities and as an effect becomes a cause of chronic tiredness, malaise and often cause of neurotic disorders [5]. In accordance to American Heart Association lack of physical activity is a fourth most important risk factor of prevalence and development of ischemic heart disease (after tobacco smoking, hypertension and elevated cholesterol level) [6]. Cardiovascular disease continue to stay a number one death cause in Poland and throughout the whole world. Physical activity plays important role at each stage of human development. Polish society is characterized with low physical activity and it's assessed that only $30 \%$ of teenagers and $10 \%$ of adults undertake satisfying level of physical activity [7].

Promoting physical activity among students of medical faculties is essentially targeted at the young people engaged in full time studying. Students have little time and little encouragement to undertake regular physical activity in any form i.e. leisure, occupational, transport-related activity.

Other countries show similar patterns, data from 2004 survey of around 2000 students entering United States medical schools saying that almost $98 \%$ of this group engage in regular (weekly) activity and the decrease in physical activity accompanied by unhealthy lifestyle and weight gain is observed during preclinical years [8].

Health promotion and primary prophylactics in accordance to National Health Care Program goals are one of the basic elements for building healthy lifestyle and should be included at every stage of education. Medical University Students, as future doctors, should not only understand the importance of physical activity but they should actively propagate it.

Understanding the importance of prophylactics and possible ways of propagating healthy life style may convince students to choose family medicine and become leaders in building healthy life styles among their future patients and communities. Potential social benefits are very high and students ought to be aware of this and practice it during academic years.

\section{Objectives}

The aim of conducted research was to assess the level of physical activity among students of the final study year of Medical and Dentistry Faculties of Wroclaw Medical University.

\section{Material and methods}

The study was conducted in summer term of 2011/2012 academic year, auditory method, ensuring anonymity. All students participating in the Public Health course at the $6^{\text {th }}$ year of medicine (281 students) and $5^{\text {th }}$ year of dentistry (88 students) were asked to take part in the study. The study was optional and intended to enroll all students of the final year of medicine and dentistry without any exclusion criteria.

Eventually 211 students took part in the study: 126 female students (59.7\%) and 85 male students (40.3\%). Out of these students 144 studied at $6^{\text {th }}$ year of Medical Faculty (82 female students (56.9\%) and 62 male students (43.1\%)) and 67 studied at Dentistry Faculty (44 female students (65.7\%) and 23 male students $(34.3 \%)$ ). The age of addressed students varied from 23 to 29 years old. In term of age students of both faculties were a homogenous group ( $\mathrm{Me}=25$ years).

The study tool was International Questionnaire of Physical Activity (IPAQ) - long. IPAQ ensures complete assessment of physical activity, it is divided into five parts out of which each one focuses on different type of physical activity undertaken in period of 7 days prior to completing the questionnaire.

IPAQ includes physical activity questions related to:

1) occupational activity (in our case taking part in study classes and lectures),

2) physical activity related to mobility,

3) domestic works, general home maintenance and looking after family,

4) physical activity of leisure time, devoted to sport, recreation and other leisure activities,

5) time spent seating (including sitting during transportation).

To calculate the level of physical activity markers of intensity were used (Metabolic Equivalent of Work; MET), enabling assessment of different types of physical activity. The average values for MET coefficient for different types of physical activity IPAQ-long:

1) walking (stroll) - $3.3 \times \mathrm{MET} / \mathrm{min} /$ week,

2) moderate activity - $4.0 \times \mathrm{MET} / \mathrm{min} /$ week,

3) moderate activity related to domestic works $-3.0 \mathrm{x}$ $\mathrm{MET} / \mathrm{min} /$ week,

4) intensive activity - $8.0 \times \mathrm{MET} / \mathrm{min} /$ week,

5) intensive activity related to domestic works $-5.5 \mathrm{x}$ $\mathrm{MET} / \mathrm{min} /$ week

6) riding bicycle as a form of transportation $-6.0 \mathrm{x}$ $\mathrm{MET} / \mathrm{min} /$ week.

Total weekly physical activity was a mean of all types of physical activities from above list in MET/min/week units.

Criteria for assigning students to particular category of physical activity take into account modern medical guidelines which say that regularity is the critical feature in physical activity. That is why the criteria include both number of days and total physical activity (expressed in MET/min/ week) of different intensities [9, 10].

Based on collected results students were divided in respect to level of total physical activity to three categories:

1) intensive physical activity - to qualify to this category one needed to fulfill at least one of two of the below criteria:

- 3 or more days of intensive physical activity, total of minimum $1500 \mathrm{MET} / \mathrm{min} /$ week,

- 7 or more days of any combination of listed activities (walking, moderate or intensive activities) exceeding $3000 \mathrm{MET} / \mathrm{min} /$ week;

2) average (satisfying) physical activity - to qualify to this category one needs to fulfill at least one of three of the below criteria:

- 3 or more days of intensive physical activity but not less than 20 min daily,

- 5 or more days of moderate physical activity or walking but not less than 30 min daily,

- 5 or more days of any combination of listed activities (walking, moderate or intensive activities) exceeding $600 \mathrm{MET} / \mathrm{min} /$ week;

3) Iow (unsatisfying) physical activity - people, who showed any physical activity, or didn't fulfill conditions to qualify for moderate or intensive level of physical activity.

\section{Statistical methods}

Median, standard deviation, $1^{\text {st }}$ and $2^{\text {nd }}$ quartiles and minimal and maximal observations were calculated to learn about standard location parameters and describe distribution of collected information. Values of MET values were calculated accordingly to questionnaire key.

To assess significance of the differences of the results in respect to variables (i.e. type of faculty, gender, level of 
physical activity) odds ratios were calculated and to assess the size of the effect Cohen's d value was used.

The results of the activity expressed in METs showed the activity levels of the students in different categories like work-related or transportation-related. Analysis of the data in search for the variables explaining the differences in the distribution physical activity (METs) was more problematic. Variables like type of faculty and gender did allow for interpretations yet statistically significant differences were observed only between gender in respect to physical activity in the domain of leisure time activity.

It suggests that there should be some other underlying reasons behind the differences in physical activity of the students. This could be related to life history of the students. Possible questions to be asked could be some of the following: what was their attitude to physical activity at earlier age and at school, how students were raised at home, what is their social class, what are their monthly budgets, what other duties they have, what hobbies, etc. This would reveal the culture and socio-economic contexts and lead to better understanding of the physical activity specific to the students.

\section{Results}

The level of students' physical activity is comparable between the faculties with slightly higher values for students of Dentistry Faculty. Overall physical activity of male students appears higher than female students (Fig. 1).
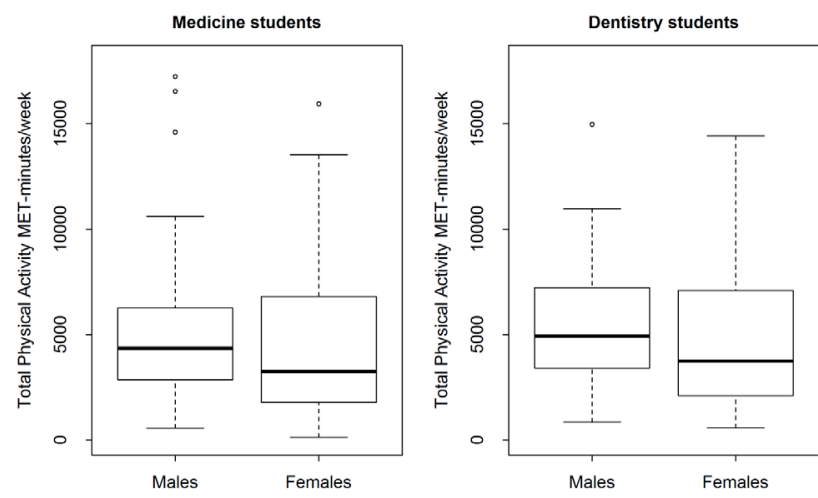

Figure 1. Total physical activity MET/min/week) divided into faculty and gender

Female students of both faculties have around $14 \%$ lower physical activity than male students. Overall students of
Dentistry Faculty have physical activity of around 3\% higher than students of Medical Faculty in concerns both female and male students of two faculties (Tab. 1).

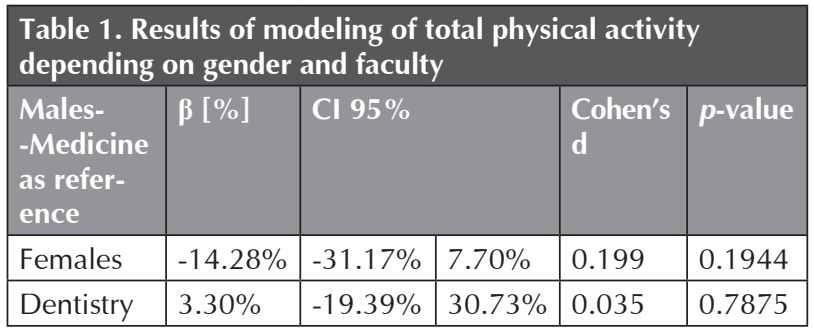

Interaction gender: faculty is not significant $\left(\mathrm{F}_{1,179}=0.0738 ; p=\right.$ 0.7862).

Basing on METs values we distinguished three levels of total physical activity and showed that $20 \%$ have high physical activity, around $35 \%$ have moderate physical activity and around $45 \%$ have low physical activity. Distributions of these three levels of physical activity were similar between the faculties which are shown in Figure 2. Male students have higher representation in high physical activity group for both faculties.
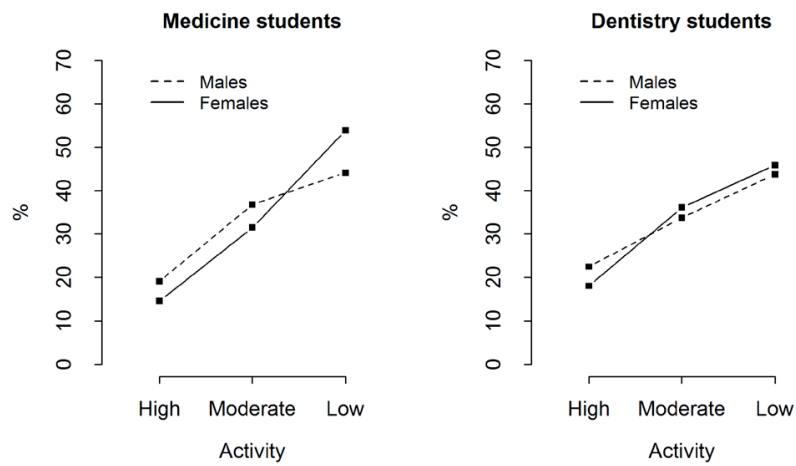

Figure 2. Total frequency of three levels of activity among faculty and gender

Total physical activity includes activities in four domains: occupational activity (in our case it is participation in study classes and lectures), transportation activities, domestic activities and leisure time activities (recreation, sport, entertainment). Data from Table 2 and 3 divide analyzed groups of physical activity in respect to faculty, gender and domain of physical activity.

Table 2. Levels of physical activity. Scores in categories

\begin{tabular}{|c|c|c|c|c|c|c|c|c|c|}
\hline \multirow{2}{*}{$\begin{array}{l}\text { Domains } \\
\text { of physical activity }\end{array}$} & \multirow{2}{*}{$\begin{array}{l}\text { Student } \\
\text { group }\end{array}$} & \multirow[t]{2}{*}{ Gender } & \multicolumn{4}{|c|}{ Physical activity [ $n]$} & \multicolumn{3}{|c|}{ Physical activity [proportions] } \\
\hline & & & Intense & Moderate & Low & Sum & Intense & Moderate & Low \\
\hline \multirow{6}{*}{$\begin{array}{l}\text { Work- } \\
\text { related }\end{array}$} & \multirow[t]{3}{*}{ medicine } & $\mathrm{F}$ & 8 & 8 & 61 & 77 & 0.10 & 0.10 & 0.80 \\
\hline & & $M$ & 8 & 7 & 36 & 51 & 0.16 & 0.14 & 0.70 \\
\hline & & total & 16 & 15 & 97 & 128 & 0.12 & 0.12 & 0.76 \\
\hline & \multirow[t]{3}{*}{ dentistry } & $\mathrm{F}$ & 4 & 10 & 22 & 36 & 0.11 & 0.28 & 0.61 \\
\hline & & $M$ & 4 & 4 & 12 & 20 & 0.20 & 0.20 & 0.60 \\
\hline & & total & 8 & 14 & 34 & 56 & 0.14 & 0.25 & 0.61 \\
\hline \multirow{6}{*}{$\begin{array}{l}\text { Transport- } \\
\text { related }\end{array}$} & \multirow[t]{3}{*}{ medicine } & $\mathrm{F}$ & 13 & 48 & 16 & 77 & 0.17 & 0.62 & 0.21 \\
\hline & & M & 7 & 39 & 5 & 51 & 0.14 & 0.76 & 0.10 \\
\hline & & total & 20 & 87 & 21 & 128 & 0.16 & 0.68 & 0.16 \\
\hline & \multirow[t]{3}{*}{ dentistry } & $\mathrm{F}$ & 9 & 21 & 6 & 36 & 0.25 & 0.58 & 0.17 \\
\hline & & $M$ & 6 & 13 & 1 & 20 & 0.30 & 0.65 & 0.05 \\
\hline & & total & 15 & 34 & 7 & 56 & 0.27 & 0.61 & 0.12 \\
\hline
\end{tabular}




\begin{tabular}{|c|c|c|c|c|c|c|c|c|c|}
\hline \multirow{2}{*}{$\begin{array}{l}\text { Domains } \\
\text { of physical activity }\end{array}$} & \multirow{2}{*}{$\begin{array}{l}\text { Student } \\
\text { group }\end{array}$} & \multirow[t]{2}{*}{ Gender } & \multicolumn{4}{|c|}{ Physical activity [n] } & \multicolumn{3}{|c|}{ Physical activity [proportions] } \\
\hline & & & Intense & Moderate & Low & Sum & Intense & Moderate & Low \\
\hline \multirow{6}{*}{$\begin{array}{l}\text { Domestic } \\
\text { and gardening- } \\
\text { related }\end{array}$} & \multirow[t]{3}{*}{ medicine } & $\mathrm{F}$ & 5 & 27 & 45 & 77 & 0.07 & 0.35 & 0.58 \\
\hline & & M & 2 & 18 & 31 & 51 & 0.04 & 0.35 & 0.61 \\
\hline & & total & 7 & 45 & 76 & 128 & 0.06 & 0.35 & 0.59 \\
\hline & \multirow[t]{3}{*}{ dentistry } & $\mathrm{F}$ & 2 & 14 & 20 & 36 & 0.06 & 0.39 & 0.55 \\
\hline & & M & 0 & 7 & 13 & 20 & 0.00 & 0.35 & 0.65 \\
\hline & & total & 2 & 21 & 33 & 56 & 0.04 & 0.37 & 0.59 \\
\hline \multirow{6}{*}{$\begin{array}{l}\text { Leisure time- } \\
\text { related }\end{array}$} & \multirow[t]{3}{*}{ medicine } & $\mathrm{F}$ & 19 & 14 & 44 & 77 & 0.25 & 0.18 & 0.57 \\
\hline & & $M$ & 22 & 11 & 18 & 51 & 0.43 & 0.22 & 0.35 \\
\hline & & total & 41 & 25 & 62 & 128 & 0.32 & 0.20 & 0.48 \\
\hline & \multirow[t]{3}{*}{ dentistry } & $\mathrm{F}$ & 11 & 7 & 18 & 36 & 0.31 & 0.19 & 0.50 \\
\hline & & M & 8 & 3 & 9 & 20 & 0.40 & 0.15 & 0.45 \\
\hline & & total & 19 & 10 & 27 & 56 & 0.34 & 0.18 & 0.48 \\
\hline
\end{tabular}

\begin{tabular}{|c|c|c|c|c|c|c|c|c|}
\hline $\begin{array}{l}\text { Domains } \\
\text { of activity }\end{array}$ & \begin{tabular}{|l|}
$\begin{array}{l}\text { Student } \\
\text { group }\end{array}$ \\
\end{tabular} & Gender & Min & Q1 & Med & $S_{n}$ & Q3 & Max \\
\hline \multirow[t]{6}{*}{ Work-related } & \multirow[t]{3}{*}{ medicine } & $\mathrm{F}$ & 0 & 0 & 0 & 0 & 300 & 6930 \\
\hline & & $M$ & 0 & 0 & 0 & 0 & 915 & 12640 \\
\hline & & total & 0 & 0 & 0 & 0 & 593 & 12640 \\
\hline & \multirow[t]{3}{*}{ dentistry } & $\mathrm{F}$ & 0 & 0 & 0 & 0 & 1493 & 2895 \\
\hline & & $M$ & 0 & 198 & 495 & 495 & 2085 & 12010 \\
\hline & & total & 0 & 0 & 363 & 396 & 1518 & 12010 \\
\hline \multirow[t]{6}{*}{ Transport-related } & \multirow[t]{3}{*}{ medicine } & $\mathrm{F}$ & 0 & 396 & 924 & 660 & 1386 & 5544 \\
\hline & & $M$ & 0 & 648 & 1386 & 841 & 2030 & 4599 \\
\hline & & total & 0 & 462 & 990 & 805 & 1980 & 5544 \\
\hline & \multirow[t]{3}{*}{ dentistry } & $\mathrm{F}$ & 0 & 396 & 1172 & 990 & 2079 & 7119 \\
\hline & & $M$ & 0 & 519.8 & 1006 & 791 & 2741 & 3834 \\
\hline & & total & 0 & 432 & 1121 & 990 & 2242 & 7119 \\
\hline \multirow{6}{*}{$\begin{array}{l}\text { Domestic and } \\
\text { gardening-related }\end{array}$} & \multirow[t]{3}{*}{ medicine } & $\mathrm{F}$ & 0 & 360 & 630 & 450 & 1200 & 9240 \\
\hline & & $M$ & 0 & 195 & 420 & 435 & 990 & 2940 \\
\hline & & total & 0 & 300 & 550 & 425 & 1129 & 9240 \\
\hline & \multirow[t]{3}{*}{ dentistry } & $\mathrm{F}$ & 0 & 213.8 & 360 & 300 & 990 & 4500 \\
\hline & & $M$ & 0 & 180 & 780 & 660 & 1271 & 2520 \\
\hline & & total & 0 & 210 & 505 & 462 & 1080 & 4500 \\
\hline \multirow{6}{*}{$\begin{array}{l}\text { Leisure time- } \\
\text { related }\end{array}$} & \multirow[t]{3}{*}{ medicine } & $\mathrm{F}$ & 0 & 438 & 1116 & 1137 & 2316 & 10420 \\
\hline & & $M$ & 0 & 720 & 1920 & 1597 & 2936 & 6713 \\
\hline & & total & 0 & 495 & 1386 & 1287 & 2697 & 10420 \\
\hline & \multirow[t]{3}{*}{ dentistry } & $\mathrm{F}$ & 0 & 371.2 & 1190 & 1101 & 2407 & 6426 \\
\hline & & $M$ & 0 & 367.5 & 1050 & 1356 & 2252 & 5040 \\
\hline & & total & 0 & 367.5 & 1190 & 1191 & 2376 & 6426 \\
\hline
\end{tabular}

Med - median; Q1, Q3 - $1^{\text {st }}$ and $3^{\text {rd }}$ quartile; $\mathrm{S}_{\mathrm{n}}$ - measure of variability, average dispersion.

For all types of activities the lowest physical activity for both faculties and gender was found in the domain of workrelated activity. Half of Medical Faculty students have no activity in that domain. Students of Dentistry Faculty have general higher levels of physical activity in work-related activity domain than Medical Faculty students. The highest physical activity for both faculties and gender was found in the domain of leisure activity. It is interesting to see the big variations in distribution of physical activity between students of the same faculty and gender.

The study showed that Dentistry Faculty students have higher activity in area of work-related activity and transportrelated activity than Medical Faculty students.
A Dentistry Faculty student has twice the chance for moderate and high physical activity than a Medical Faculty student, respectively odds ratio for occupational activity was 1.88 and transportation activity 1.78. Differences between the gender show 1.5 higher odds for high physical activity of male student comparing to female student these results were comparable for both faculties Medical and Dentistry students $(\mathrm{OR}=1.44$ and $\mathrm{OR}=1.43$ respectively).

In the area of leisure time activity male student show higher levels of activity than female student. The odds for male student spending the leisure time very actively were twice the odds of female student $(O R=2.01)$. Domestic activities showed comparable odds between gender and faculty (Tab. 4). 


\begin{tabular}{|l|l|l|l|l|l|l|}
\hline Table 4. Odds ratios of undertaking intense physical activity among participants \\
\hline $\begin{array}{l}\text { Domains } \\
\text { of activity }\end{array}$ & $\begin{array}{l}\text { Odds ratio } \\
\text { Dentistry vs. Medicine }\end{array}$ & $\mathbf{C l} 95 \%$ & $\boldsymbol{p}$-value & $\begin{array}{l}\text { Odds ratio } \\
\text { Males vs. Females }\end{array}$ & CI 95\% & $p$-value \\
\hline Work-related & 1.88 & $0.97 ; 3.65$ & 0.0622 & 1.44 & $0.76 ; 2.74$ & 0.2681 \\
\hline Transport-related & 1.76 & $0.91 ; 3.39$ & 0.0905 & 1.43 & $0.77 ; 2.65$ & 0.2543 \\
\hline $\begin{array}{l}\text { Domestic and gardening- } \\
\text { related }\end{array}$ & 0.98 & $0.52 ; 1.84$ & 0.9442 & 0.8 & $0.44 ; 1.45$ & 0.4592 \\
\hline Leisure time-related & 1.08 & $0.59 ; 1.97$ & 0.7939 & 2.01 & $1.14 ; 3.53$ & 0.0153 \\
\hline
\end{tabular}

\section{Discussion}

Regular physical activity is essential in the prevention of many chronic diseases and is crucial to reducing the incidence of cardiovascular diseases, which are still the first cause of death in Poland and in the world. It improves the quality of life for people of all ages.

Recent research (i.e. WOBASZ) indicate that $50-60 \%$ of adult Poles are characterized by unsatisfactory level of physical activity, this is particularly true for women, residents of large urban areas and those with lower socio-economic status [12]. There is no international studies taking into account Poland and other European Union countries, but on the basis of Eurobarometer surveys and studies WOBASZ it can be concluded that physical activity of Poles is similar to the average of the EU countries [13]. Even in developing countries, with extensive programs promoting healthy lifestyle, physical activity is one of the most difficult goals to achieve $[6,14]$. Research indicates that the most common reason for the insufficient physical activity is low awareness of the need for the regular sport and recreation activities [7]. The CBOS survey from 2013 showed that Poles declared their willingness to participate in various forms of movement $-66 \%$ of Poles declared engaging sports or physical exercise in the last year, out of which $40 \%$ undertook activities regularly and 26\% occasionally. Among the motivations for undertaking physical activity Poles declared health in the first place (up to $70 \%$ ), then successively pleasure $(61 \%)$, need to relieve stress $(47 \%)$, desire to meet with friends $(34 \%)$, care about the aesthetics of the body (24\%) and other needs, including compulsory physical education (15\%) [15]. Different results were obtained by Polish Central Statistical Office (GUS), who asked the Poles about their participation in sport and physical recreation, expenditure for this purposes and the motivation for undertaking physical activity - the study covered the period from October 2011 to September 2012 [16]. According to GUS around 46\% of Poles (slightly more men - nearly $49 \%$ ) participated in sports or recreational activities, but only $20 \%$ undertook these activities regularly, with pleasure as a main motivating factor (around $71 \%)$. Only one in ten Poles participated in sport and recreation for health [16]. The results of our study are similar to the results of the GUS - students of both departments have shown physical activity in leisure time at a satisfactory level at around $52 \%$ (here also the men were more active than women). Strengthening the motivation to undertake physical activity is the first step towards improving the health status of the population, especially in reduction of many lifestyle diseases. Such change can be achieved by: launching programs that promote activity in the society, promotion of recreational physical activity, broadening the curriculum of physical education at every level of education, increasing awareness of positive impact of physical activity $[9,10,17]$.

EU platform on diet - 2009 report, physical activity and health confirms the active participation of primary care physicians, members EUROPREV (European Network for Prevention and Health Promotion in Family Medicine and General Practice), in activities to promote physical activity through intensive health education $[18,19]$. CPME
(Standing Committee of European Doctors), which aims to promote the highest standards of medical education and medical practice, the aim of which is to achieve the highest quality of care for all patients in Europe, recommends prescribing doctors 'prescription' physical activity as an adjunctive treatment for diseases related to elevated BMI [20].

In our study, nearly half of all respondents (around 45\%) demonstrated unsatisfactory level of general physical activity, the female students of both faculties showed lower activity than the male students. It should be noted that the highest activity of students of both gender was in the domain of leisure time activity.

Our results are in line with the results of population studies conducted in the south-eastern regions of Poland in 2009 by the University of Rzeszów, where approximately $48 \%$ of women and $44 \%$ of men aged $20-25$ years presented an unsatisfactory level of physical activity (studies carried out with use of IPAQ-short questionnaire) [21]. They are also convergent with data describing the activity of selected female students of medical faculties, which also showed, among most of the surveyed students, the lack of well-developed habits of undertaking leisure time physical activity [22]. Our findings correspond with the results of other research centers in Poland. Unsatisfactory level of physical activity concerns a significant group of students of the Medical University - it is worth recalling at this point that the sampled are final year students - shortly becoming doctors. Doctors active participation in undertaking physical activity in promoting healthy lifestyle should be taken into account to ensure effectiveness in this matter. Actions in this area should not only be included in postgraduate training, but also undergraduate.

We found studies showing that Universities in other countries bear the same problem. Striking was to see that students of Uniformed Services University (USU) also describe the issue at hand [8] where 4-year study showed decline in physical activity of the students, who were particularly vulnerable to decline in physical activity during preclinical years. USU students were on active duty in either US Army, Navy or Air Force and were expected to maintain set level of fitness, yet their fitness levels declined significantly during preclinical years of studying.

Interesting project undertaken at the Brody School of Medicine [23] where 75 third year students enrolled to weight management program during 12-14 weeks Family Medicine Clerkship experience (University offered 2 extra credit points for joining the program) showed high acceptance among students to participate in such programs).

This learning experience intended to learn-by-doing about process of weight management. Authors refer to US Surgeons General Satcher and Benjamin call on physicians to be role models during the obesity epidemic. Being role models require to personally represent advocated issue and or to reach it through active engagement. All students completing the assignment where of the opinion that this experience will help them to be more supportive and understanding to their future patients.

US Surgeon General in the Call To Action To Prevent and Decrease Overweight and Obesity [24] underlined several times the need for role models at the struggle to bringing 
the society more aware and active in reducing the burden of overweight and obesity in the society. Leadership and becoming role models should be spread evenly throughout health, social and educational systems.

Other American study conducted at University of Missouri Department of Family and Community Medicine showed that the problem of insufficient physical activity is not just as high among medical students which show higher levels of physical activity than the general public but among residents and attending physicians [25].

This overview gives in our opinion basis to conduct series of researches of the current levels of physical activity among students of Medical Faculties and practicing physicians, discuss study curricula and concepts of continues education.

Currently, the Ministry of Science and Higher Education in "The Teaching Standards For Particular Fields Of Education" recommends the 60 hours (2 ECTS) of physical education in the curriculum of higher education, but does not specify any additional requirements and does not impose forms of conduct of these classes. It appears advisable to introduce physical education for each year of study [26].
Newly introduced professions to Polish health and social care sector such as health carer and child carer are, among others, expected to support medical personnel and form care teams with physicians and/or nurses as leaders. This may give a unique chance to extend general care to environmental and home care and provide people with support to maintain and manage behaviour related health conditions in a professional and institutionalized fashion.

\section{Conclusions}

Our study showed the need of health promotion in contests of physical activity among students of both faculties. The lowest levels of physical activity during academic year of both male and female students was in the work-related domain of physical activity. It creates a need for modifications of the study curriculum by adding additional sport classes and promoting attitudes of undertaking physical activity during other than study related activities.

Education of future physicians should provide them with basic skills to become leaders and role models to their patients and co-workers especially in primary care and family medicine.

Source of funding: This work was funded by the Department of Social Medicine, Wroclaw Medical University, statutory grant no. ST-606.

Conflict of interest: The authors declare no conflict of interests.

\section{References}

1. EU Working Group «Sport and Health» (2008). EU Physical Activity Guidelines [cited 10.01.2014]. Available from URL: http:// ec.europa.eu/sport/what-we do/doc/health/pa guidelines 4th consolidated draft en.pdf.

2. Drabik J. Profilaktyka zdrowia - aktywność fizyczna czy aktywność ruchowa. Wychow Fiz Zdr 2011; 5: 4-8.

3. Schnohr P, Lange P, Scharling H. Long-term physical activity in leisure time and mortality from coronary heart disease, stroke, respiratory diseases and cancer. The Copenhagen City Heart Study. Eur J Cadiovasc Prev Rehabil 2006; 13(2): 173-179.

4. Campbell KL, McTiernan A. Exercise and biomarkers for cancer prevention studies. J Nutr 2007; 137: 161-191.

5. Wen CP, Wai JP, Tsai MK. Minimum amount of physical activity for reduced mortality and extended life expectancy: a prospective cohort study. Lancet 2011; 378: 1244-1253.

6. Donald M, Lloyd J, Yuling H. Defining and setting national goals for cardiovascular health promotion and disease reduction: the American Heart Association's Strategic Impact Goal Through 2020 and Beyond. Circulation 2010; 121: $586-613$.

7. National Health Program on 2007-2015 years, nr 90/2007 as the document of the Council of Ministers from $15^{\text {th }}$ of May 2007 [cited 15.01.2014]. Available from URL: http://www.mz.gov.pl/_data/assets/pdf_file/0020/12494/zal_urm_npz_90_15052007p. pdf.

8. Stephens MB, Cochran C, Hall JM, et al. Physical fitness during medical school: a 4-year study at the Uniformed services university. Fam Med 2012; 44(10): 694-697.

9. WHO - Global recommendations on physical activity for health (2014) [cited 12.02.2014]. Available from URL: http://www. who.int/dietphysicalactivity/factsheet recommendations/en/index.html.

10. WHO - Green Papers: "Promoting healthy diets and physical activity: a European dimension for the prevention of overweight, obesity and chronic diseases", (2006) [cited 12.02.2014]. Available from URL: http://ec.europa.eu/health/ph_determinants/ life_style/nutrition/green_paper/nutrition_gp_rep_en.pdf.

11. Rousseeuw PJ, Croux C. Alternatives to the median absolute deviation. JASA 1993; 88(424): 1273-1283.

12. Drygas W, Kwaśniewska M, Szcześniewska D, i wsp. Ocena poziomu aktywności fizycznej dorosłej populacji Polski. Wyniki badania WOBASZ. Kardiol Pol 2005; 63, 6(Supl. 4): 636-640.

13. Wojtyniak B, Goryński P, red. Sytuacja zdrowotna ludności Polski. Warszawa: PZH; 2008 [cited 20.01.2014]. Available from URL: http://www.pzh.gov.pl/page/fileadmin/user_upload/PZH_Raport_2008.pdf.

14. EU Report. EU guidelines for physical activity. Recommended policies supporting physical activity positively affecting the health. Brussels; 2008 [cited 20.01.2014]. Available from URL: http://ec.europa.eu/sport/documents/pa_guidelines_4th_consolidated_draft_pl.pdf.

15. CBOS Statement: BS/129/2013: Physical activity of Polen [cited 05.02.2014]. Available from URL: http://www.cbos.pl/SPISKOM.POL/2013/K_129_13.pdf.

16. GUS Report: Polish participation in sport and physical recreation in 2012 [cited 05.02.2014]. Available from URL: http://www. stat.gov.pl/cps/rde/xbcr/gus/KTS_Uczestnictwo_pol_w_sporcie_w_2012.pdf.

17. Górski J. Fizjologia wysiłku i treningu fizycznego. Warszawa: Wydawnictwo Lekarskie PZWL; 2011: $235-243$.

18. WHO - White Papers: A Strategy for Europe on Nutrition, Overweight and Obesity (2007) [cited 15.02.2014]. Available from URL: http://eur-lex.europa.eu/LexUriServ/LexUriServ.do?uri=COM:2007:0279:FIN:PL:PDF.

19. EU Platform on Diet, Physical Activity and Health - 2009 Annual Report [cited 16.02.2014]. Available from URL: http:// ec.europa.eu/health/ph_determinants/life_style/nutrition/platform/docs/eu_platform_2009frep_en.pdf.

20. CPME Manifest (2014) [cited 16.04.2014]. Available from URL: http://www.cpme.eu/manifesto/.

21. Pańczyk W. Physical activity inhabitants of south-eastern Polish regions on the threshold of the twenty-first century, 2009 [cited 15.01.2014]. Available from URL: http://www.lider.szs.pl/biblioteka/download.php?plik_id=1640\&f=artykul_1640.doc.

22. Zadarko E, Barabasz Z, Nizioł E. Ocena poziomu aktywności fizycznej studentek wybranych kierunków medycznych na tle badań populacyjnych. Rzeszów: UR; 2011: 188-194.

23. Schmidt S, Rice A, Kolasa K. Teaching by example - educating medical students through a weight management experience. Fam Med 2013; 45(8): 572-575. 
24. Essential Elements to Prevent Chronic Diseases and Obesity [cited 20.01.2014]. Available from URL: http://www.cdc.gov/ nccdphp/dnpa/pdf.

25. Williams AS, Williams CD, Cronk NJ, et al. Understanding the exercise habits of residents and attending physicians: a mixed methodology study. Fam Med 2015; 47(2): 118-123.

26. Zadarko E, Junger J, Barabasz Z. Aktywność fizyczna studentów Euroregionu Karpackiego. Rzeszów: UR; 2010 : 50-51.

Address for correspondence:

Dr n. med. Dagmara Gaweł-Dąbrowska

Katedra i Zakład Medycyny Społecznej

Uniwersytet Medyczny

ul. Bujwida 44

50-345 Wrocław

Tel.: +48 601 750-266

E-mail: dagmara.gawel-dabrowska@umed.wroc.pl

Received: 17.02.2015

Revised: 16.03.2015

Accepted: 16.04.2015 